\title{
Long-Term Testing of WC-Ni-Fe Coating as an Inert Anode in a Low- Temperature Electrolyte for Aluminum Production
}

\author{
Chuhua LIU ${ }^{1,2}$, Yudong WANG ${ }^{1,2 *}$, Bin YANG $^{1}$, Yongnian Dai ${ }^{1,3}$ \\ ${ }^{1}$ National Key Laboratory for Clean Application of Complex Non-ferrous Metal Resources, Kunming University of \\ Science and Technology, Kunming 650093, China \\ ${ }^{2}$ Faculty of Public Safety and Emergency Management, Kunming University of Science and Technology, Kunming \\ 650093, China \\ ${ }^{3}$ Metallurgical and Chemistry Division of Chinese Academy of Engineering \\ crossref http://dx.doi.org/10.5755/j01.ms.26.2.21574
}

Received 15 May 2018; accepted 10 November 2018

\begin{abstract}
The behaviour of WC-Ni-Fe coating on $2 \mathrm{Cr} 13$ and $\mathrm{X} 3 \mathrm{CrNiMo18}-12-3$ stainless steel substrates was investigated in the context of their application as inert anode materials in a low-temperature $\left(850{ }^{\circ} \mathrm{C}\right)$ electrolyte $\left(50 \mathrm{wt} . \% \mathrm{AlF}_{3}-45 \mathrm{wt} . \% \mathrm{KF}-\right.$ $5 \mathrm{wt} . \% \mathrm{Al}_{2} \mathrm{O}_{3}$ ) by long-term testing around $50 \mathrm{~h}$ for aluminum production. The results show that the materials were corroded in a controlled manner and the extrapolated corrosion rates of WC-Ni-Fe/X3CrNiMo18-12-3 anode was $5.8 \mathrm{~cm}$ per year, which is acceptable from an industrial perspective. The total contamination level of anode constituents in the deposited metal was as low as $0.283 \mathrm{wt} . \%$. These encouraging results seemed to be related in part to the $\mathrm{X} 3 \mathrm{CrNiMo18-}$ 12-3 substrate that allows only very slow penetration of oxygen atoms into the inner part. Post-electrolysis examination of the anodes indicates that the substrate material is one of the most important factors that determine the erosion resistance of coating inert anode. The results of electrolysis using $2 \mathrm{Cr} 13$ and $\mathrm{X} 3 \mathrm{CrNiMo18}-12-3$ substrates indicate that the electrical current is another important factor for the erosion resistance of inert anode coatings.

Keywords: carbide, ceramics, coatings, corrosion, oxidation, electrical conductivity.
\end{abstract}

\section{INTRODUCTION}

Ever since the Hall-Heroult process for the industrial production of aluminum was developed a century ago, the research for an inert anode material has been pursued. The current process that involves dissolving $\mathrm{Al}_{2} \mathrm{O}_{3}$ in fused cryolite $\left(\mathrm{NaF}-\mathrm{AlF}_{3}\right)$ followed by direct current electrolysis, discharges $\mathrm{CO}_{2}$ at a sacrificial carbon anode while $\mathrm{Al}$ is deposited at the bottom of the cell. The main drawbacks of this process are the release of perfluorocarbons, high values of specific $\mathrm{CO}_{2 \text {-equiv }}$ emission, high carbon cost, and high energy consumption as the production each kilogram of $\mathrm{Al}$ releases $7.42 \mathrm{~kg} \mathrm{CO}_{2 \text {-equiv }}$ [1] and requires the consumption of $0.4-0.5 \mathrm{~kg}$ of carbon [2] and $0.186 \mathrm{GJ}$ of energy. Greenhouse gases emitted during $\mathrm{Al}$ electrolysis constitutes $2.5 \%$ of the world's anthropogenic $\mathrm{CO}_{2 \text {-equiv }}$ emission [3]. With an inert anode, the total electrolyte reaction can be represented as:

$2 \mathrm{Al}_{2} \mathrm{O}_{3}=4 \mathrm{Al}+3 \mathrm{O}_{2}$.

The basic requirements for the candidate materials of inert anodes are: low corrosion rate, good electronic conductivity, no significant contamination of the electrolyzed aluminum, thermal stability up to electrolysis temperature, adequate resistance to thermal shock, affordability, and ease of fabrication and simplicity of electrical connection in comparison to ceramic [4].

In 1986, Aluminum Company of America (Alcoa) initiated a lot of research work on the use of ferrites [5] and developed a new cermet material consisting of a nickel ferrite-nickel oxide ceramic containing copper as a metal phase to provide good electrical conductivity combined along with excellent corrosion resistance. Many new materials have been developed for use in aluminum production with an emphasis on electrode materials, and many authors such as Sadoway [6, Belyaev], Hryn and Sadoway [8], Windisch [9], and Zöllner [10] have conducted extensive studies on them. The development of new Al electrolysis cells with inert anodes and wetted cathodes promises not only significant environmental benefits but also energy savings and reduction in capital and operating costs [4]. The substitution of the consumable carbon anodes by inert anodes in the $\mathrm{Al}$ electrolysis process is a long-standing goal [11] of the primary aluminum industry].

Metallic anodes have shown promising properties as inert anodes for $\mathrm{Al}$ production in low-temperature electrolytes due to their ability to form a protective adherent, and electronically conducting oxide-rich scale on their surface during Al electrolysis [13].Unfortunately, the alloys present a two -phase microstructure; for example, $\mathrm{Cu}-\mathrm{Fe}-\mathrm{Ni}$ alloys form a $\mathrm{Cu}$-rich phase and a $\mathrm{Fe}-\mathrm{Ni}$ rich phase, which decreases their corrosion resistance as the iron-rich area is preferentially dissolved during $\mathrm{Al}$ electrolysis, inducing the formation of iron fluoride corrosion tunnels in the anode scale [14].Goupil showed that the monophasic $\mathrm{Cu}-\mathrm{Ni}-\mathrm{Fe}$ alloy [15 obtained by mechanical alloying ] under an oxygen atmosphere [17] produced $\mathrm{Al}$ that had a purity of $99.8 \%$ in a low temperature $\mathrm{KF}-\mathrm{AlF}_{3}$-based electrolyte and the anode

${ }^{*}$ Corresponding author. Tel.: 8613987196558.

E-mail address: wyd@kmust.edu.cn (Y. Wang) 
dissolution rate was estimated as $0.8 \mathrm{~cm}_{\text {year }}^{-1}$ [18]. Such promising results were obtained at 20 A current for $20 \mathrm{~h}$ and they need to be validated using prolonged electrolysis tests. However, the fabrication of large electrodes is challenging because the high chemical homogeneity of the oxidation film of the alloys must be conserved during the electrolysis. Recently, Y. Zhu has fabricated Fe-30Ni-5NiO anodes for low-temperature $\mathrm{Al}$ electrolysis by spark plasma sintering [19].

In the present study, we combined the mechanical strength of cermet and alloy inert anode by applying high velocity oxygen fuel (HVOF) to achieve a coarse-grained structure of the WC-Ni-Fe metal matrix composite (MMC) coating on the substrates of $2 \mathrm{Cr} 13$ stainless steel and $\mathrm{X} 3 \mathrm{CrNiMo18-12-3}$ stainless steel. WC-Fe-Ni is a wellknown cermet as tungsten carbide-Fe-Ni which is famous for its high temperature oxidation resistance. HVOF is an alternative resurfacing technique to traditional flame spraying. HVOF has been successfully applied for sintering various materials such as metals, ceramics, and composites to achieve a highly dense, mechanically bonded, and hardened surface during hydraulic component reclamation. $\mathrm{WC}-\mathrm{Ni}-\mathrm{Fe}$ coating provides longer working life, greater resistance to thermal shock, better electronic conductivity, and enhanced dimensional stability up to electrolysis temperature. Lab tests demonstrated that $\mathrm{WC}-\mathrm{Ni}-\mathrm{Fe}$ coating can extend inert anode life by up to $50 \%$ in longterm electrolysis and seemed ideal for high temperatures and highly oxidizing environments.

This work evaluates the applicability of WC-Fe-Ni as alternative materials for inert anodes used for aluminum electrolysis to obtain materials with better properties. The metal phase consulted the final composition studied by Goupil ${ }^{[18]}$. This is because the oxides of $\mathrm{Fe}$ and $\mathrm{Ni}\left(\mathrm{Fe}_{2} \mathrm{O}_{3}\right.$ and $\mathrm{NiO}$ ) form $\mathrm{NiFe}_{2} \mathrm{O}_{4}$, which has very low solubility in the electrolyte. This paper verified whether WC can improve thermal stability and antioxidant performance of $\mathrm{Ni}-\mathrm{Fe}$ alloy inert anode in low temperature aluminum electrolyte, both on the properties of the sprayed coating and on the performance in electrolysis tests.

\section{EXPERIMENT}

\subsection{Powder synthesis}

Two different substrates for WC-Ni-Fe coating were investigated (see Table 1). All the powders used in this study were prepared from commercial grade chemicals. The suppliers and specifications were as follows: Fe: Beijing General Research Institute of Mining \& Metallurgy (BGRIMM), electronic grade, purity $\geq 99.9,300$ mesh; WC40-Ni60: BGRIMM, pigment grade, purity $\geq 98.0$, 150 mesh.

WC30-Ni40-Fe30 (wt.\%) powder was prepared by ball milling at pilot scale using an attritor mill fabricated inhouse. Typically, $1.00 \mathrm{~kg}$ Fe and $2.33 \mathrm{~kg}$ WC-Ni powders were introduced in a stainless steel tank (capacity of $10 \mathrm{~L}$ ) containing $24 \mathrm{~kg}$ of $1 / 4$ to 1 inch stainless steel balls, corresponding to a ball-to-powder mass ratio (BPR) of 10:1. The milling was performed for $16 \mathrm{~h}$ at $1 \mathrm{r} / \mathrm{s}$ under an Ar flow $\left(15 \mathrm{~cm}^{3} \mathrm{~min}^{-1}\right)$. No binder and dispersion were added to the powder, as Fe present in the powder was considered to be sufficiently ductile to produce dense and machinable green bodies. The milling yield, defined as the ratio of the powder masses before and after milling was around $99 \%$. The composition of the as-milled powder was in accordance with its nominal composition (within $1-2 \mathrm{wt} . \%$ ).

Table 1. Coating composition investigated

\begin{tabular}{|l|c|c|c|}
\hline \multicolumn{1}{|c|}{ Coating } & $\begin{array}{c}\text { Substrate } \\
\text { chemical } \\
\text { composition }\end{array}$ & $\begin{array}{c}\text { WC } \\
\text { size, } \mu \mathrm{m}\end{array}$ & $\begin{array}{c}\text { Distribution, } \\
\mu \mathrm{m}\end{array}$ \\
\hline $\begin{array}{l}\mathrm{WC}-\mathrm{Ni}- \\
\mathrm{Fe} / \mathrm{X} 3 \mathrm{CrNiMo} 18- \\
12-3\end{array}$ & $\begin{array}{c}\mathrm{Ni}: 10.0-14.0 \\
\mathrm{Cr}: 16.0-18.5\end{array}$ & $\leq 20$ & $15-45$ \\
\hline $\mathrm{WC}-\mathrm{Ni}-\mathrm{Fe} / 2 \mathrm{Cr} 13$ & $\begin{array}{c}\mathrm{Ni}: \leq 0.60 \\
\mathrm{Cr}: 12.00-14.00\end{array}$ & $\leq 20$ & $15-45$ \\
\hline
\end{tabular}

\subsection{Thermal spray coating}

\subsubsection{Substrate preparation}

Substrates of two different compositions were prepared using X3CrNiMo18-12-3 and 2Cr13 stainless steel in this study, and substrate material with approximate dimensions of $\Phi 32 \times L 106 \mathrm{~mm}$ were used.

\subsubsection{Thermal spraying powder materials}

The metal phase was based on the $\mathrm{Cu}_{65} \mathrm{Ni}_{20} \mathrm{Fe}_{15}$ alloy composition proposed by Goupil by removing $\mathrm{Cu}$ [18]. Ni has better wetting characteristics than copper towards the oxide phase [5], leading to smaller metal grains in the thermal spray coating samples. $\mathrm{Fe} / \mathrm{Ni}$ molar ratio in stoichiometric $\mathrm{NiFe}_{2} \mathrm{O}_{4}$ is 2 .

\subsubsection{Spraying}

Table 2. HVOF parameters applied

\begin{tabular}{|l|c|c|}
\hline & $\begin{array}{c}\text { Pressure of gas, } \\
\mathrm{MPa}\end{array}$ & Gas flow, $\mathrm{dm}^{-3} / \mathrm{s}$ \\
\hline $\mathrm{H}_{2}$ & 0.97 & 0.92 \\
\hline $\mathrm{O}_{2}$ & 1.2 & 0.47 \\
\hline Air, MPa/F, FMR & $0.62 / 44$ & $0.65 / 52$ \\
\hline Carrier gas & 1.0 & 0.73 \\
\hline Powder feed rate, g/s & \multicolumn{2}{|c|}{0.63} \\
\hline Spray distance, mm & \multicolumn{2}{|c|}{210} \\
\hline $\begin{array}{l}\text { Coating thickness, } \\
\mu \mathrm{m}\end{array}$ & \multicolumn{2}{|c|}{$70-100$} \\
\hline F: gas flow, FMR: flow meter reading (\% of maximum flow) \\
\hline
\end{tabular}

The spraying equipment used was a Sulzer Metco Diamond Jet DJ2600 HVOF system designed for hydrogen fuel gas. The coatings were sprayed on cylinders of X3CrNiMo18-12-3 and 2Cr13 stainless steel respectively. Diameter and length of the cylinders were $\Phi 32 \times L 106 \mathrm{~mm}$. Prior to spraying, the samples were degreased using acetone, preheated to $\sim 90{ }^{\circ} \mathrm{C}$ and grit blasted using alumina granulate with a grit size of $0.6-1.0 \mathrm{~mm}$ in order to improve the adherence between the substrate and coating. The average surface roughness was approximately in the range of a few microns. During spraying, the samples were rotated in a lathe. Surface temperature of the specimens was kept between 80 and $120^{\circ} \mathrm{C}$. The spray parameters applied are as summarized in Table 2, and the energy input and spray distance were taken from the study by S. Kailash [20]. Before testing the coatings need not be ground and polished. 


\subsubsection{Electrical conductivity measurements}

The variation of electrical conductivity with temperature was measured using a simple device constructed in-house, with two sets of alligator clips connected to the cylinder sample and another tip connected to the sockets of the ohmmeter to continuously monitor the resistance in a closed furnace; the setup was heated from room temperature to $900{ }^{\circ} \mathrm{C}$ in a high-oxygen atmosphere. It must be noted that the present electrical conductivity measurement was under simple conditions, and it needs to be validated again under prolonged industrial operating conditions.

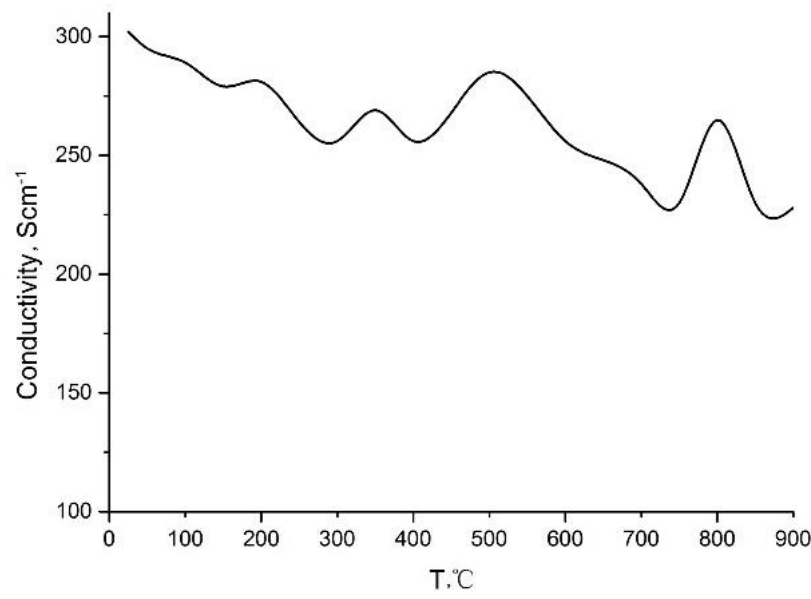

Fig. 1. Electrical conductivity versus temperature for WC30-Ni40$\mathrm{Fe} 30$ (X3CrNiMo18-12-3)

The electrical conductivity $\left(\mathrm{Scm}^{-1}\right)$ as a function of temperature for the materials WC30-Ni40Fe30/X3CrNiMo18-12-3 in this work is shown in Fig.1. Good conductivity is, in general, a property typical of metals. The newly developed material exhibited strong metal-like behavior as its conductivity gradually decreased with increasing temperature, reaching $250 \mathrm{Scm}^{-1}$ at $800{ }^{\circ} \mathrm{C}$. The conductivity is significantly higher than that of pure nickel ferrite and there were no remarkable changes as the temperature varied from 25 to $900{ }^{\circ} \mathrm{C}$. The highest electrical conductivity of pure ferrite as measured by Olsen is $250 \mathrm{Scm}^{-1}$ [21].

\subsubsection{Electrolysis test}

For the electrolysis test, a 2Cr13 (X3CrNiMo18-12-3) stainless steel cylinder protected by a WC40-Ni60 coating was screwed on to the coated sample to serve as the current lead. Electrolysis was performed at $850{ }^{\circ} \mathrm{C}$ in air using a one-electrode configuration cell fabricated in-house (see Fig. 2).It consists of an alumina tube interred in a graphite crucible. The inner diameter of the crucible is $120 \mathrm{~mm}$. A circular graphite disc is placed at the bottom of the cell to serve as cathode. In order to ensure that the deposited aluminum would wet the cathode and generate enough crystal seeds at the start of the experiment, $10 \mathrm{~g}$ of high purity $\mathrm{Al}$ was added into the electrolyte prior to electrolysis. The rest of the cell bottom was insulated with a plate of alumina $10 \mathrm{~mm}$ thick. The crucible cathode was polarized through a 6-mm X3CrNiMo18-12-3 rod while the cathode and anode were provided through X3CrNiMo18-12-3 holder protected from oxidation by a WC-Ni coating.

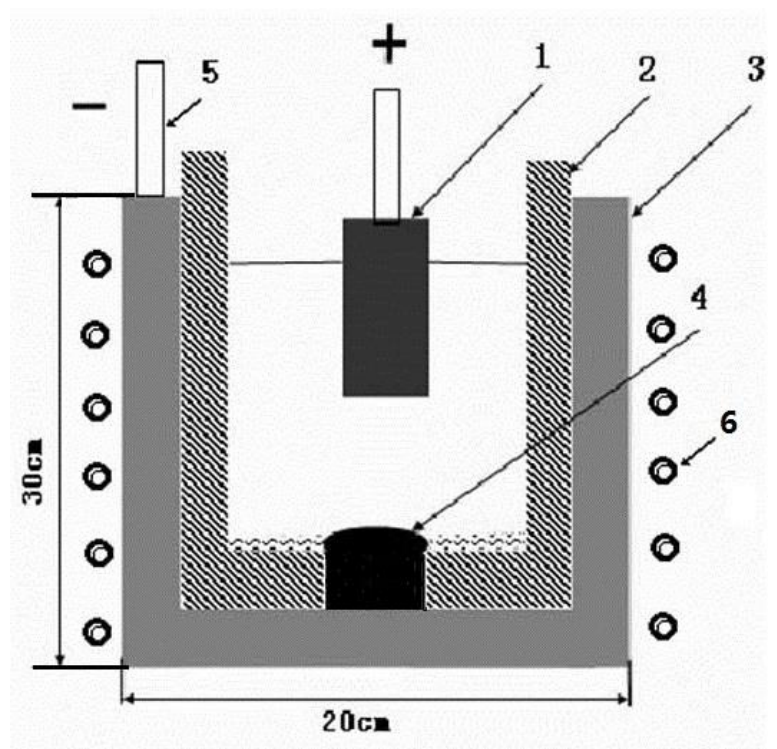

Fig. 2. Schematic diagram of electrolysis cell: $1-\mathrm{WC}-\mathrm{Ni}-\mathrm{Fe}$ inert anode; 2 -alumina inner crucible; 3 -graphite crucible; 4-melting aluminum cathode; 5-X3CrNiMo18-12-3 electrode; 6 -silicon carbide heating

The geometric surface area of the anode is more than $50 \mathrm{~cm}^{2}$ when immersed in the electrolyte while only a part of the bottom electrode $\left(\sim 8 \mathrm{~cm}^{2}\right)$ is the effective area. The anode-cathode distance is $2 \mathrm{~cm}$. The tube containing the electrolyte is made of sintered alumina and the electrolyte composition is 50 wt.\% $\mathrm{AlF}_{3}-45$ wt.\% KF-5 wt.\% $\mathrm{Al}_{2} \mathrm{O}_{3}$. Eight grams of alumina are added every 30 min during the electrolysis, which is less than theoretical amount as its consumption is compensated by the dissolution of the alumina crucible. Electrolysis was performed at an anode current density of $0.9 \mathrm{~A} \cdot \mathrm{cm}^{-2}$ for $\sim 50 \mathrm{~h}$. Current and voltage measurements were conducted periodically during the $\sim 50 \mathrm{~h}$ of electrolysis to determine the evolution of the cell electrical resistance.

\section{RESULTS AND DISCUSSION}

Marinating corrosion test results show that Hastelloy $\mathrm{N}$ alloy and $\mathrm{X} 3 \mathrm{CrNiMo18-12-3}$ stainless steel show continuous corrosion in LiF-NaF-KF molten salt ${ }^{[22]}$. WC$\mathrm{Ni}-\mathrm{Fe}$ coating significantly improved the corrosion resistance of $\mathrm{X} 3 \mathrm{CrNiMo18-12-3}$ stainless steel at high temperature.

During the first $30 \mathrm{~min}$ of electrolysis, the electrical resistance between the cathode and anodewas measured at 5 min intervals to study the dissolution process of the anode material. Subsequently, resistance was measured every half an hour just before the addition of alumina. The resistance was indicative of the extent of anode erosion, and the average value of every four measurements were plotted in Fig. 1.

Fig. 3 shows the evolution of the electrical resistance for $\sim 50 \mathrm{~h}$ electrolysis in a low-temperature $\left(850^{\circ} \mathrm{C}\right) \mathrm{KF}-$ $\mathrm{AlF}_{3}$ electrolyte at $\mathrm{I}_{\text {anode }}=0.9 \mathrm{~A} \mathrm{~cm}^{-1}$ with the WC30-Ni40Fe30 coating anode.

During the first $1 \mathrm{~h}$ of electrolysis, the electrical resistance decreases slightly from $\sim 0.12$ to $\sim 0.1 \Omega$ as the oxidation film of the Ni-Fe alloy on the anode surface 
dissolved into the electrolysis before the production of oxygen.

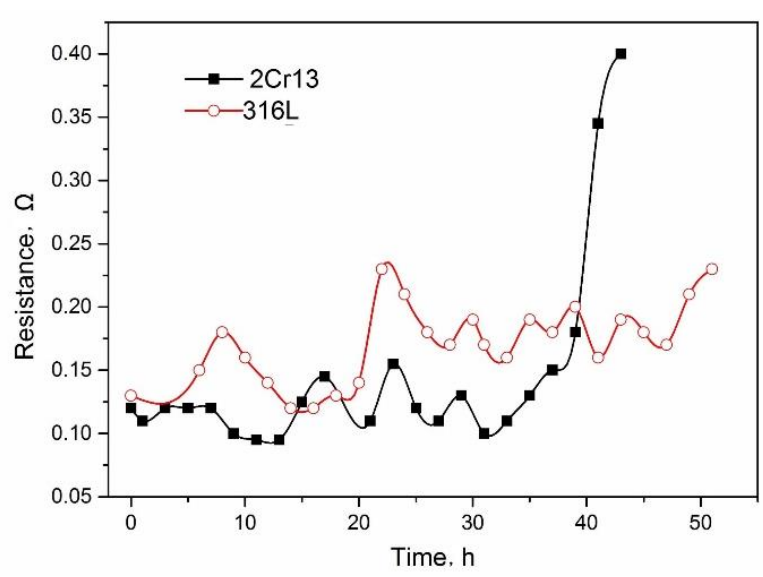

Fig. 3. Relationship of resistance vs. time in electrolysis for WC$\mathrm{Ni}-\mathrm{Fe} / 2 \mathrm{Cr} 13$ (X3CrNiMo18-12-3) stainless steel inert anode

In the subsequent $10-15 \mathrm{~h}$ of electrolysis, a rapid increase of the electrical resistance was observed. This phenomenon is attributed to the growth of the $\mathrm{NiFe}_{2} \mathrm{O}_{4}$ on the surface of the anode. In the subsequent $\sim 10 \mathrm{~h}$ of electrolysis, a slight fluctuation between 0.1 and $0.22 \Omega$ was observed, suggesting that the anode had reached its steady state between the respective rates of oxide formation and dissolution. However, from about $37 \mathrm{~h}$ of electrolysis, the electrical resistance of the anode with $2 \mathrm{Cr} 13$ substrate rapidly increases to reach about $0.4 \Omega$ at the early end of electrolysis, which can be attributed to the rapid decrease in the electrical conductivity of the anode. This increase in the electrical resistance induces an increase in the cell voltage, which can even prevent electrolysis.

Pictures of the WC-Ni-Fe/2Cr13 and X3CrNiMo1812-3 substrate anodes after aluminum electrolysis at $37 \mathrm{~h}$ and $52 \mathrm{~h}$, respectively are presented in Fig. 4 . There was significant decrease in the dimensions of the $\mathrm{WC}-\mathrm{Ni}-$ $\mathrm{Fe} / 2 \mathrm{Cr} 13$ coating anode, while no major physical degradation of the $\mathrm{WC}-\mathrm{Ni}-\mathrm{Fe} / \mathrm{X} 3 \mathrm{CrNiMo18-12-3}$ anode was observed. A slight increase of $3 \%$ in the anode diameter was associated with the formation of a surface oxide layer and the presence of residual electrolyte. The WC-Ni-Fe coating that covered the part of the electrode not immersed in the bath was obviously less eroded than the coating on the immersed part of the anode because of the absence of electrolytic dissolution. The oxide growth of metallic phase in the coating and substrate may induce the increase of substrate volume increase under the WC-Ni-Fe coating, which is no longer effective for protecting the anode from the corrosive bath and oxygen.

With respect to the $2 \mathrm{Cr} 13$ and $\mathrm{X} 3 \mathrm{CrNiMo18}-12-3$ stainless steel substrates, it can be disputed whether the substrate material is one of the most important factors for the erosion resistance of inert anode coatings from the result of Fig. 3 and Fig. 4. The $2 \mathrm{Cr} 13$ is a martensitic stainless steel that is composed of $\mathrm{Cr} \sim 13 \mathrm{wt} . \%$ and $\mathrm{Ni}<0.06$ wt.\% while on the other hand, $\mathrm{X} 3 \mathrm{CrNiMo18-12-3}$ is an austenitic stainless steel that is composed of $\mathrm{Cr} \sim 18 \mathrm{wt} \%$ and $\mathrm{Ni}<16 \mathrm{wt} . \%$. In the temperature range of
$1173-1920 \mathrm{~K}$, the standard Gibbs free energy of the formation of $\mathrm{Cr}_{2} \mathrm{O}_{3}$ is [23]:

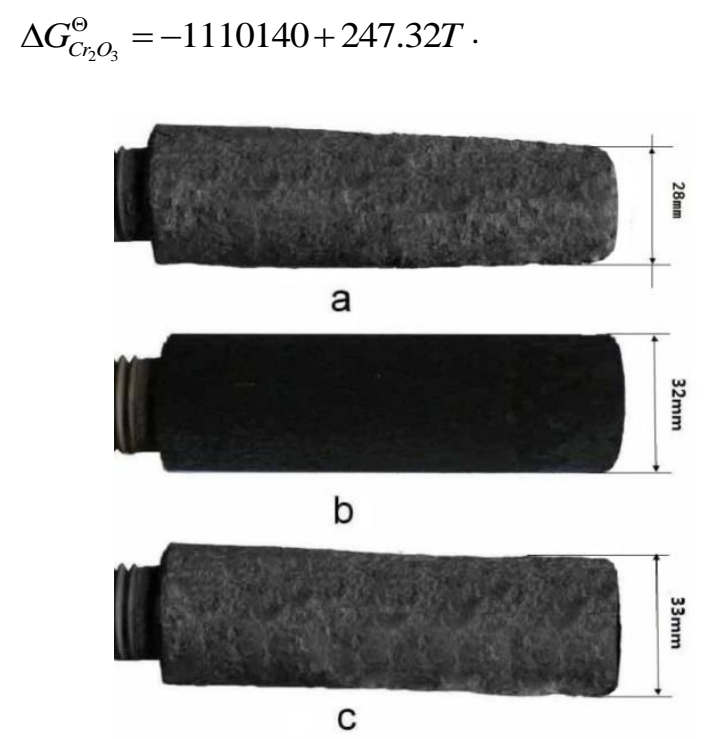

Fig. 4. Pictures of $\mathrm{WC}-\mathrm{Ni}-\mathrm{Fe} / 2 \mathrm{Cr} 13$ and $\mathrm{X} 3 \mathrm{CrNiMo} 18-12-3$ substrate anode after/before aluminum electrolysis: a-WC-Ni-Fe/2Cr13 after 37 h electrolysis; b-WC-Ni$\mathrm{Fe} / 2 \mathrm{Cr} 13$ after $72 \mathrm{~h}$ marinate; c-WC-NiFe/X3CrNiMo18-12-3 after 52h electrolysis

In the temperature range of $277-1726 \mathrm{~K}$, the standard Gibbs free energy of the formation of $\mathrm{NiO}$ is:

$\Delta G_{N i O}^{\Theta}=-232450+83.59 T$

At the electrolysis temperature of $1123 \mathrm{~K}$, $\Delta G_{\mathrm{Cr}_{2} \mathrm{O}_{3}}^{\Theta}=-832400 \mathrm{~kJ} / \mathrm{mol}, \Delta G_{\mathrm{NiO}}^{\Theta}=-138578 \mathrm{~J} / \mathrm{mol}$.

By comparing the $\Delta G^{\Theta}$ values at the electrolysis temperature, it can be concluded that the oxidation of $\mathrm{Cr}$ is much easier than that of $\mathrm{Ni}$.

The results of electrolysis with $2 \mathrm{Cr} 13$ and X3CrNiMo18-12-3 substrates show that the electrical current is another important factor for erosion resistance of inert anode coatings compared with marinated sample. Fig. 5 shows that the outmost coating experiences no major physical degradation, but the oxygen atom prefers to pass through the WC30-Ni40-Fe30 coating and diffuse inward to oxidize the substrate. As the $\mathrm{O}$ atom has a diameter less than that of W, Cr and Ni atom, it can diffuse inward through the vacancy of crystal lattice. Furthermore, the higher the electrolysis temperature, the faster the diffusion speed and the more the vacancies; for example the vacancy of copper crystal lattice is $2 \times 10^{3} / \mathrm{cm}^{3}$ at $493 \mathrm{~K}$ and $5 \times 10^{18} / \mathrm{cm}^{3}$ at $1273 \mathrm{~K}$. The diffusion coefficient ( $D$ in Eq. 3 ) of vacancy can be described by Eq. 4 [ 24]:

$D=\frac{1}{6} v \cdot Z \cdot p_{v} \cdot C_{v} \cdot d^{2}$

where $v$ is the frequency of crystal lattice, $Z$ the coordination number, $p_{v}$ the probability of atoms leaping into vacancies, $C_{v}$ the vacancy concentration, and $d$ the leaping distance. The $v, C_{v}$ and $p_{v}$ increase rapidly when temperatures increase, as a result, the $D$ increases rapidly. The higher the temperature is, the faster the oxygen atoms diffuse into the 
substrate. There are a lot of vacancies in the coating and substrate at electrolysis temperature.

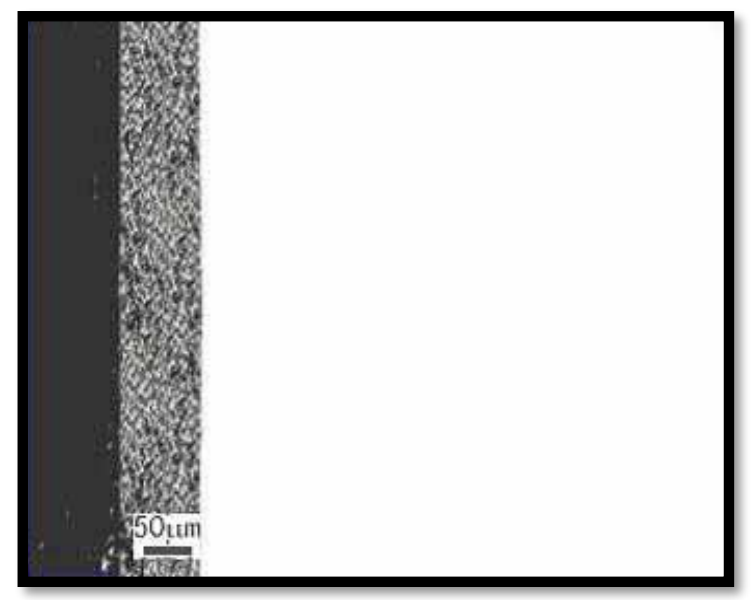

a

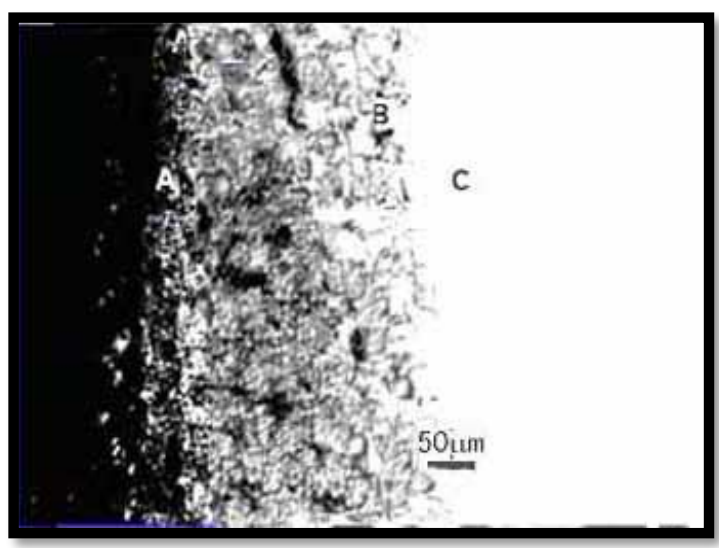

b

Fig. 5. Micrograph of $\mathrm{WC}-\mathrm{Ni}-\mathrm{Fe} / \mathrm{X} 3 \mathrm{CrNiMo18}-12-3$ inert anode: $\mathrm{a}-$ after $72 \mathrm{~h}$ marination in electrolyte; b-after $52 \mathrm{~h}$ electrolysis

The third most important factor that affects the erosion resistance of inert anode coating is the nascent oxygen atoms which were produced by electrolysis from anode. Fig. 5 shows the cross-section SEM images of the WC-Ni$\mathrm{Fe} / 2 \mathrm{Cr} 13$ coating anode after marinating for $72 \mathrm{~h}$ in electrolyte without the application of current and after $52 \mathrm{~h}$ electrolysis. The sample clearly shows that no erosion occurs after $72 \mathrm{~h}$ marinating in electrolyte at $850{ }^{\circ} \mathrm{C}$, and the interface between the coating and the substrate is clearly demarcated and intact. It indicates that the $\mathrm{WC}-\mathrm{Ni}-\mathrm{Fe}$ coating on anode components do not show a significant degree of dissolution into the electrolyte. On the other hand, the $\mathrm{WC}-\mathrm{Ni}-\mathrm{Fe} / 2 \mathrm{Cr} 13$ coating is so strongly eroded that it breaks off (see Fig. 5 b) after 52 h electrolysis and cannot provide the cross-section image.

Fig. 5 b shows that no major physical degradation of the inner part of WC-Ni-Fe/X3CrNiMo18-12-3 coating occurs, while on the outside, a surface oxide layer $\left(\mathrm{Fe}_{2} \mathrm{O}_{3}\right.$ film, Area A) forms, which is very flaky and adheres poorly to the inner coating. A large amount of oxide is detected in the coating, which tends to accumulate at interface of the outmost $\mathrm{Fe}_{2} \mathrm{O}_{3}$ film and $\mathrm{WC}-\mathrm{Ni}-\mathrm{Fe}$ coating, and these oxides permit the formation of a large number of passages in the $\mathrm{Fe}_{2} \mathrm{O}_{3}$ film which allow oxygen to enter and oxidize the substrate. Fig. 5 b shows a slight erosion and increase in volume of the X3CrNiMo18-12-3 substrate (Area B), and substrate allowing only the very slow transfer of oxygen atoms into the inner part (Area C). All these oxides demonstrate the significant inward diffusion of oxygen atoms. The oxide growth may induce volume increase of substrate and the formation of large cracks in the coating, making the coating ineffective in protecting the anode from corrosive vapors and oxygen. The formation of oxide in the substrate and the volume increase are assumed to be deleterious for the long-term stability of the anode by leading a decrease in the electrical conductivity of the $\mathrm{WC}-$ $\mathrm{Ni}-\mathrm{Fe} / 2 \mathrm{Cr} 13$ anode resulting in a significant increase of the cell electrical resistance after about $42 \mathrm{~h}$ of electrolysis as shown in Fig. 3.

Three different samples of produced aluminum were analyzed at the end of $50 \mathrm{~h}$ of electrolysis. The mean concentrations of $\mathrm{Fe}$ and $\mathrm{Ni}$ in the produced $\mathrm{Al}$ are around $0.25 \%$ and $0.05 \%$ respectively, corresponding to an $\mathrm{Al}$ purity of $99.7 \%$. Note that the present contamination levels in produced $\mathrm{Al}$ and bath were obtained in transient conditions and need to be validated again. Moreover, the low anode dissolution rate may contribute to the low cathode/anode surface area ratio $\left(\mathrm{A}_{\mathrm{c}} / \mathrm{A}_{\mathrm{a}}=1.5\right.$, in comparison, $A_{c} / A_{a}=34$ in G.Goupil paper [18]).

The oxide layer on the substrate is about $350 \mu \mathrm{m}$ after $52 \mathrm{~h}$ electrolysis, the extrapolated corrosion rates in $\mathrm{cm}$ per year of operation calculated from the linear behavior is $5.8 \mathrm{~cm}$ per year for the $\mathrm{WC}-\mathrm{Ni}-\mathrm{Fe} / \mathrm{X} 3 \mathrm{CrNiMo18}-12-3$ inert anode. In addition, interdiffusion of oxygen leads to the oxidation of the coating first and then possibly the substrate. After long-term electrolysis test, the $\mathrm{WC}-\mathrm{Ni}-\mathrm{Fe}$ coating inert anode was damaged too heavy to provide high quality high magnification cross-sectional SEM images to clearly show as-deposited coated samples. In the next research works, the type and location or distribution of the oxides would be studied to verify whether the oxidation process can produce more voids/cracks for the tested samples.

\section{CONCLUSIONS}

1. The extrapolated corrosion rates of $\mathrm{WC}-\mathrm{Ni}-$ $\mathrm{Fe} / \mathrm{X} 3 \mathrm{CrNiMo18-12-3}$ anode is $5.8 \mathrm{~cm}$ per year in a low-temperature electrolyte, which is acceptable from an industrial perspective and show that $\mathrm{WC}-\mathrm{Ni}-\mathrm{Fe}$ is very promising inert anode for aluminum electrolysis. Total contamination level of anode constituents in the deposited metal is as low as 0.283 wt.\% (A199.00 (GB/T 1196-2002))

2. Electrolysis testing for $\sim 50 \mathrm{~h}$ in a potassium cryolitebased electrolyte shows that the substrate material is one of the most important factors for erosion resistance of inert anode coatings.

3. The low erosion rate seems to be partly related to the X3CrNiMo18-12-3 substrate allowing only the very slow transfer of oxygen atoms into the inner part.

\section{Acknowledgements}

The authors are grateful to the financial support from 
the Kunming University of Science and Technology and Yunnan Provincial Science and Technology Department, without which, this work could not have been undertaken.

\section{REFERENCES}

1. Choate, W., Green, J. Technoeconomic Assessment of the Carbothermic Reduction Process for Aluminum Production Essential Readings in Light Metals: Aluminum Reduction Technology 2 2006: pp. 1070-1075. https://doi.org/10.1007/978-3-319-48156-2_156

2. Frank, W.B. Aluminum. In: Ullman's Encyclopedia of Industrial Chemistry VCH Publishers $A \quad 1$ 1985: pp. $459-460$. https://doi.org/10.1002/14356007.a01_459.pub2

3. Steinfeld, A., Thompson, G. Solar Combined Thermochemical Processes for $\mathrm{CO}_{2}$ Mitigation in the Iron, Cement, and Syngas Industries Energy 19 1994: pp. $1077-1081$. https://doi.org/10.1016/0360-5442(94)90096-5

4. Kvande, H., Haupin, W. Inert Anodes for AI Smelters: Energy Balances and Environmental Impact JOM 53 2001: pp. 29-33. https://doi.org/10.1007/s11837-001-0205-6

5. Weyand, J.D. DeYoung, D.H., Ray, S.P., Tarcy, G., Baker, F.W. Inert Anodes for Aluminum Smelting, Final Report Aluminum Company of America, Alcoa Laboratories, Alcoa Center, 1986, DOE No. DOE/CS/40158-20.

6. Sadoway, D.R. A Materials Systems Approach to Selection and Testing of Nonconsumable Anodes for the Hall Cell Light Metals, 1990, ed. C.A. Bickert Warrendale PA: TMS, 1990: pp. $403-407$.

7. Belyaev, A.I., Studentsov, A.E. Electrolysis of Alumina with Non-combustible (metallic) Anodes Legkic Metal 6 1937: pp. 17-22.

8. Hryn, J.N., Sadoway, D.R. Cell Testing of Metal Anodes for Aluminum Electrolysis Light Metals, Warrendale, PA 1993: pp. $475-483$.

9. Windisch, C.F., Electrochem, J. An Electrochemical Impedance Study on Cermet Anodes in Alumina-Saturated Molten Cryolite Journal of the Electrochemical Society 138 1991: pp. 2027-2029.

10. Zöllner, C. Dimensionsstabile Elektroden für die Schmelzflusselektrolyse, Berichtsnummer BMFT-FB-T 85 186, Bundesministerium für Forscung und Technologie, Bonn, Germany 1985.

11. Roadmap, I.A. A Framework for Technology Development, Aluminum Association. Inc., Washington, 1998.

12. Aluminum Industry Technology Roadmap. Aluminum Association, Inc., Washington, 2003.

13. Beck, T.R., Brooks, R.J. Non-consumable Anode and Lining for Aluminum Electrolytic Reduction Cell U.S. Patent 5, 284, 562, 1994.

14. Beck, T.R., MacRae, C.M., Wilson, N.C. Metal Anode Performance in Low-temperature Electrolytes for Aluminum Production Metallurgical and Materials Transactions B 42 2011: pp. 807-813. https://doi.org/10.1007/s11663-011-9511-8

15. Helle, S., Pedron, M., Assouli, B., Davis, B., Guay, D. Structure and High-Temperature Oxidation Behaviour of $\mathrm{Cu}-$ $\mathrm{Ni}-\mathrm{Fe}$ Alloys Prepared by High-energy Ball Milling for Application as Inert Anodes in Aluminium Electrolysis Corrosion Science 52 2010: pp. 3348-3355. https://doi.org/10.1016/j.corsci.2010.06.011

16. Helle, S., Brodu, B., Davis, B., Guay, D., Roué, L. Influence of the Iron Content in $\mathrm{Cu}-\mathrm{Ni}$ Based Inert Anodes on Their Corrosion Resistance for Aluminium Electrolysis Corrosion Science 53 2011: pp. 3248-3253. https://doi.org/10.1016/j.corsci.2011.05.069

17. Helle, S., Tresse, M., Davis, B., Guay, D., Roué, L. Mechanically Alloyed $\mathrm{Cu}-\mathrm{Ni}-\mathrm{Fe}-\mathrm{O}$ Based Materials as Oxygen-Evolving Anodes for Aluminum Electrolysis Journal of the Electrochemical Society 159 2012: pp. $62-68$. https://doi.org/10.1149/2.028204jes

18. Goupil, G., Bonnefont, G., Idrissi, H., Guay, D., Roué, L. Consolidation of Mechanically Alloyed $\mathrm{Cu}-\mathrm{Ni}-\mathrm{Fe}$ Material by Spark Plasma Sintering and Valuation as Inert Anode for Aluminum Electrolysis Journal of Alloys and Compounds 580 2013: pp. 256-261. https://doi.org/10.1016/j.jallcom.2013.05.128

19. Zhu, Y., He, Y., Wang, D. Fe-30Ni-5NiO Alloy as Inert Anode for Low-Temperature Aluminum Electrolysis JOM 63 2011: pp. $45-49$. https://doi.org/10.1007/s11837-011-0076-4

20. Kailash, S., Praveen, A.S., Suresh, S. International Journal of Chemical Tech Research, CODEN (USA): IJCRGG ISSN: 0974-4290 6 2014: pp. 3346-3348.

21. Olsen, E., Thonstad, J. Nickel Ferrite as Inert Anodes in Aluminum Electrolysis: Part I Material Fabrication and Preliminary Testing Journal of Applied Electrochemistry 29 1999: pp. $293-299$. https://doi.org/10.1023/A:1003460220418

22. Xiangbin, D. Graduate University of Chinese Academy of Sciences (Shanghai Institute of Applied Physics), 2015.

23. Ling, Y.J., Che, Y.C., Liu, X.X. Handbook of Thermodynamic Data on Inorganic Maters, Press of Northeastern University, 1993.

24. Zheng, Z.Q. Foundation of Materials Science, Press of Central South University, 2005. 